\title{
Characterization of Core Sample Collected from the Saltstone Disposal Facility
}

\author{
A.D. Cozzi \\ A.J. Duncan
}

December 2009

Savannah River National Laboratory Savannah River Nuclear Solutions Aiken, SC 29808

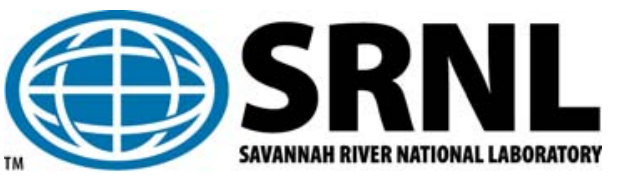


SRNL-STI-2009-00804

Revision 0

\section{DISCLAIMER}

This work was prepared under an agreement with and funded by the U.S. Government. Neither the U.S. Government or its employees, nor any of its contractors, subcontractors or their employees, makes any express or implied:

1. warranty or assumes any legal liability for the accuracy, completeness, or for the use or results of such use of any information, product, or process disclosed; or

2. representation that such use or results of such use would not infringe privately owned rights; or

3. endorsement or recommendation of any specifically identified commercial product, process, or service.

Any views and opinions of authors expressed in this work do not necessarily state or reflect those of the United States Government, or its contractors, or subcontractors.

\section{Printed in the United States of America \\ Prepared for \\ U.S. Department of Energy}




\section{REVIEWS AND APPROVALS}

AUTHORS:

A.D. Cozzi, Engineering Process Development Date

A.J. Duncan, Materials Applications \& Process Technology

Date

TECHNICAL REVIEW:

C.A. Langton, Engineering Process Development

Date

APPROVAL:

A.B. Barnes, Manager

Date

Engineering Process Development

Date

S.L. Marra, Manager

Environmental \& Chemical Process Technology Research Programs

J.E. Occhipinti, Manager

Date

Waste Solidification Engineering 


\section{EXECUTIVE SUMMARY}

During the month of September 2008, grout core samples were collected from the Saltstone Disposal Facility, Vault 4, cell E. This grout was placed during processing campaigns in December 2007 from Deliquification, Dissolution and Adjustment Batch 2 salt solution. The 4QCY07 Waste Acceptance Criteria sample collected on 11/16/07 represents the salt solution in the core samples. Core samples were retrieved to initiate the historical database of properties of emplaced Saltstone and to demonstrate the correlation between field collected and laboratory prepared samples.

Three samples were collected from three different locations. Samples were collected using a twoinch diameter concrete coring bit.

In April 2009, the core samples were removed from the evacuated sample container, inspected, transferred to PVC containers, and backfilled with nitrogen. Samples furthest from the wall were the most intact cylindrically shaped cored samples. The shade of the core samples darkened as the depth of coring increased. Based on the visual inspection, sample 3-3 was selected for all subsequent analysis.

The density and porosity of the Vault 4 core sample, $1.90 \mathrm{~g} / \mathrm{cm}^{3}$ and $59.90 \%$ respectively, were comparable to values achieved for laboratory prepared samples. X-ray diffraction analysis identified phases consistent with the expectations for hydrated Saltstone. Microscopic analysis revealed morphology features characteristic of cementitious materials with fly ash and calcium silicate hydrate gel.

When taken together, the results of the density, porosity, x-ray diffraction analysis and microscopic analysis support the conclusion that the Vault 4, Cell E core sample is representative of the expected waste form. 


\section{TABLE OF CONTENTS}

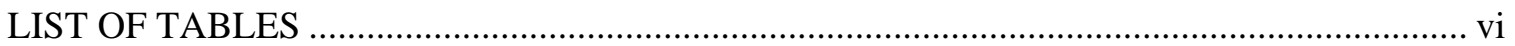

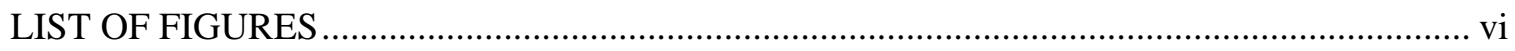

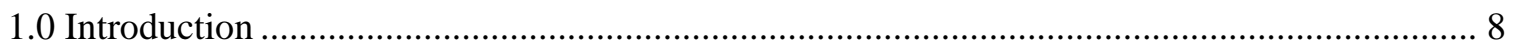

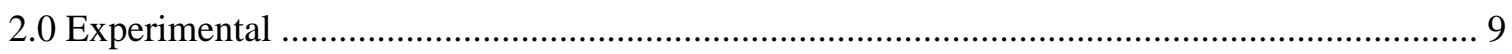

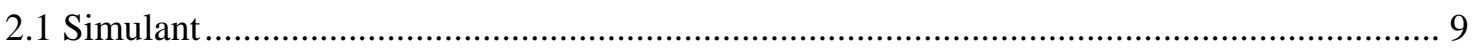

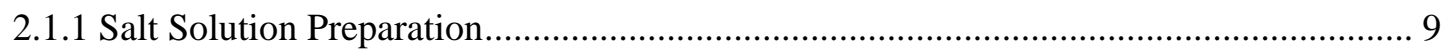

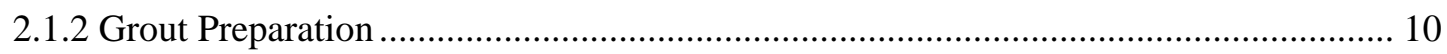

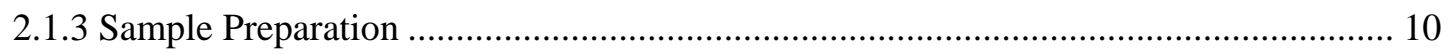

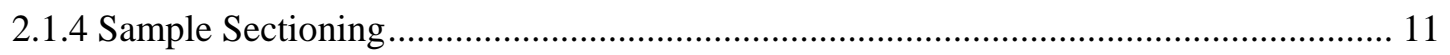

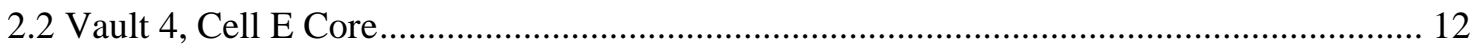

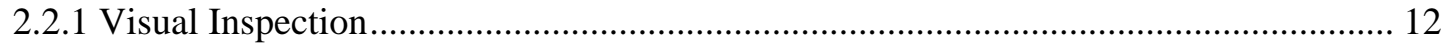

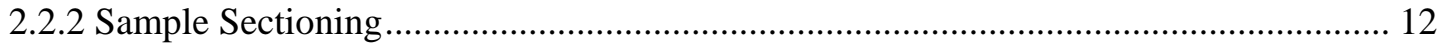

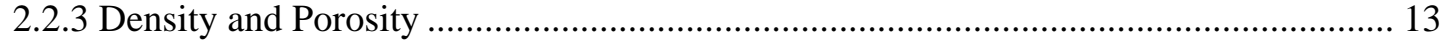

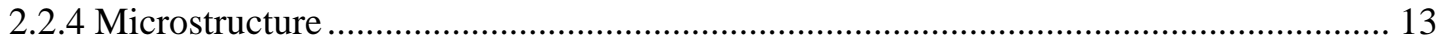

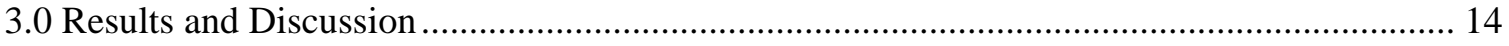

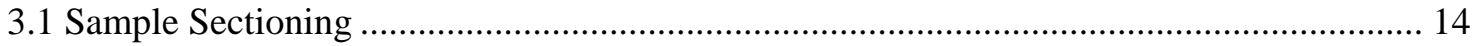

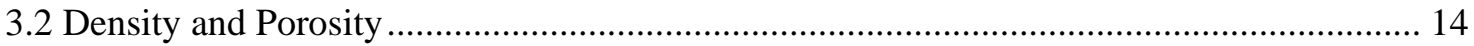

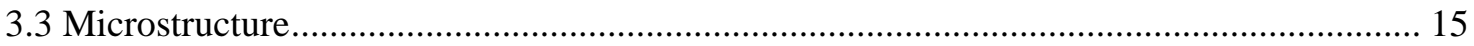

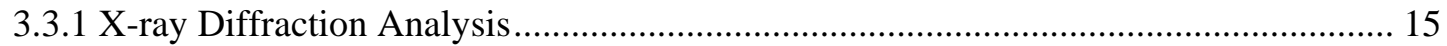

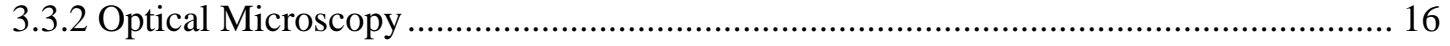

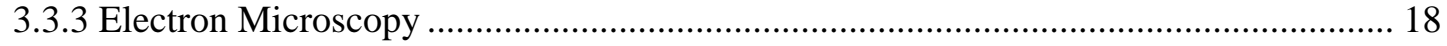

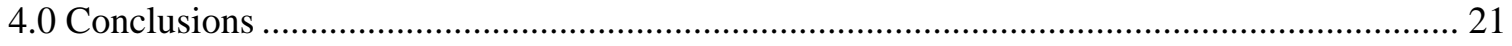

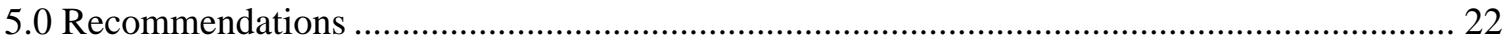

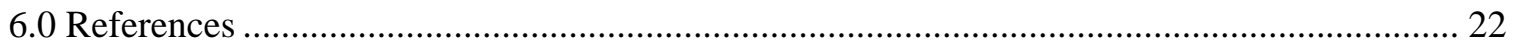


SRNL-STI-2009-00804

Revision 0

\section{LIST OF TABLES}

Table 2-1. Composition of Tank 50 as of 11/30/07 as Reported by WCS. …................................ 9

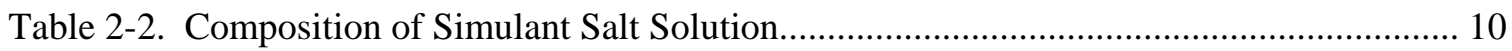

Table 2-3. Saltstone Mix Proportions for Simulant Grout. …..................................................... 10

Table 3-1. Mass of Core Fragments used to Calculate Density and Porosity.............................. 14

Table 3-2. Bulk Density and Porosity of Core Sample 3-3 Using ASTM C 642........................ 14

\section{LIST OF FIGURES}

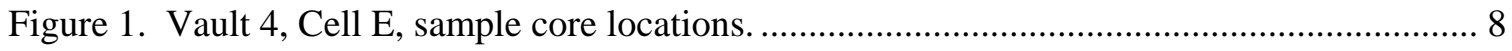

Figure 2. Simulated grout samples cast for method development............................................. 11

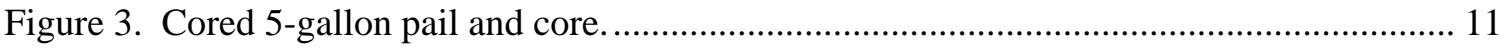

Figure 4. Schematic of miter box saw used for sectioning core samples.................................... 12

Figure 5. Stainless Steel Vault 4 Sample Container used to transport/store core samples........... 12

Figure 6. Sample 3-3. 5.5” long cylinder and associated fragments. ........................................ 12

Figure 7. X-ray diffraction analysis of the three core samples collected from cell position 3..... 15

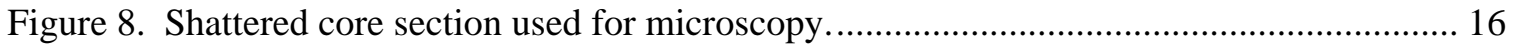

Figure 9. Mounted Vault 4 core specimen fragment interior prior to polishing, 100x................. 17

Figure 10. Polished Vault 4 core sample noting fly ash and porosity sites, 100x...................... 17

Figure 11. Micrographs showing the as-fractured surface of a fragment of the Vault 4 core sample and the corresponding BSE image, 2.5x. 18

Figure 12. Representative micrographs of the fractured core sample. Top-Secondary electron image showing the morphology of the Vault 4 core sample. Bottom-Corresponding backscatter electron image annotated with the EDS spectra positions in Figure 13.............. 19

Figure 13. EDS spectra for the four locations annotated in Figure 12.................................... 20

Figure 14. SEM micrographs of the polished Vault 4 core sample, 200x. Top-SEI and

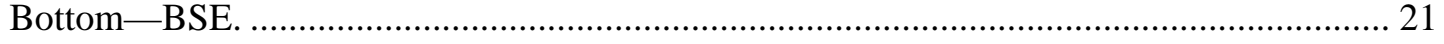




\section{LIST OF ABBREVIATIONS}

$\begin{array}{ll}\text { BSE } & \text { backscattered electron } \\ \text { CSH } & \text { calcium silicate hydrate } \\ \text { DDA } & \text { Deliquification, Dissolution and Adjustment } \\ \text { EDS } & \text { Energy Dispersive X-ray Spectroscopy } \\ \text { ETP } & \text { Effluent Treatment Project } \\ \text { RRSE } & \text { Robotics, Remote \& Specialty Equipment } \\ \text { SDF } & \text { Saltstone Disposal Facility } \\ \text { SEI } & \text { Secondary Electron Image } \\ \text { SEM } & \text { scanning electron microscopy } \\ \text { SPF } & \text { Saltstone Production Facility } \\ \text { SRNL } & \text { Savannah River National Laboratory } \\ \text { TTQAP } & \text { Task Technical and Quality Assurance Plan } \\ \text { WAC } & \text { Waste Acceptance Criteria } \\ \text { WCS } & \text { Waste Characterization System } \\ \text { XRD } & \text { X-ray Diffraction Analysis }\end{array}$




\subsection{Introduction}

During the month of September 2008, grout core samples were collected from the Saltstone Disposal Facility (SDF), Vault 4, cell E. ${ }^{1}$ This grout was placed during processing campaigns in December 2007 from Deliquification, Dissolution and Adjustment (DDA) Batch 2 salt solution. The 4QCY07 Waste Acceptance Criteria (WAC) sample collected on 11/16/07 represents the salt solution in the core samples. ${ }^{2}$ In the time between the collection of the WAC sample and the campaign where the collected samples were poured, approximately 9,000 gallons of waste concentrate from the Effluent Treatment Project (ETP) and 15,000 gallons of inleakage from the Tank 50 pump bearings was added to the Tank 50 contents represented by the WAC analysis.

The Savannah River National Laboratory Remote and Specialty Equipment (SRNL-RSE) group developed a method to retrieve core samples from the SDF. ${ }^{3}$ A total of 9 samples were obtained from three different locations, Figure 1. Three samples were collected at each location. A twoinch diameter concrete coring bit was used to collect the samples. Coring could be performed either dry or with water (to assist in coring and removal of sample). The cored samples were transferred from the core bit to stainless steel tubes and evacuated. The cores were shipped to SRNL and transferred to clear polyvinylchloride tubes and backfilled with nitrogen. ${ }^{4}$

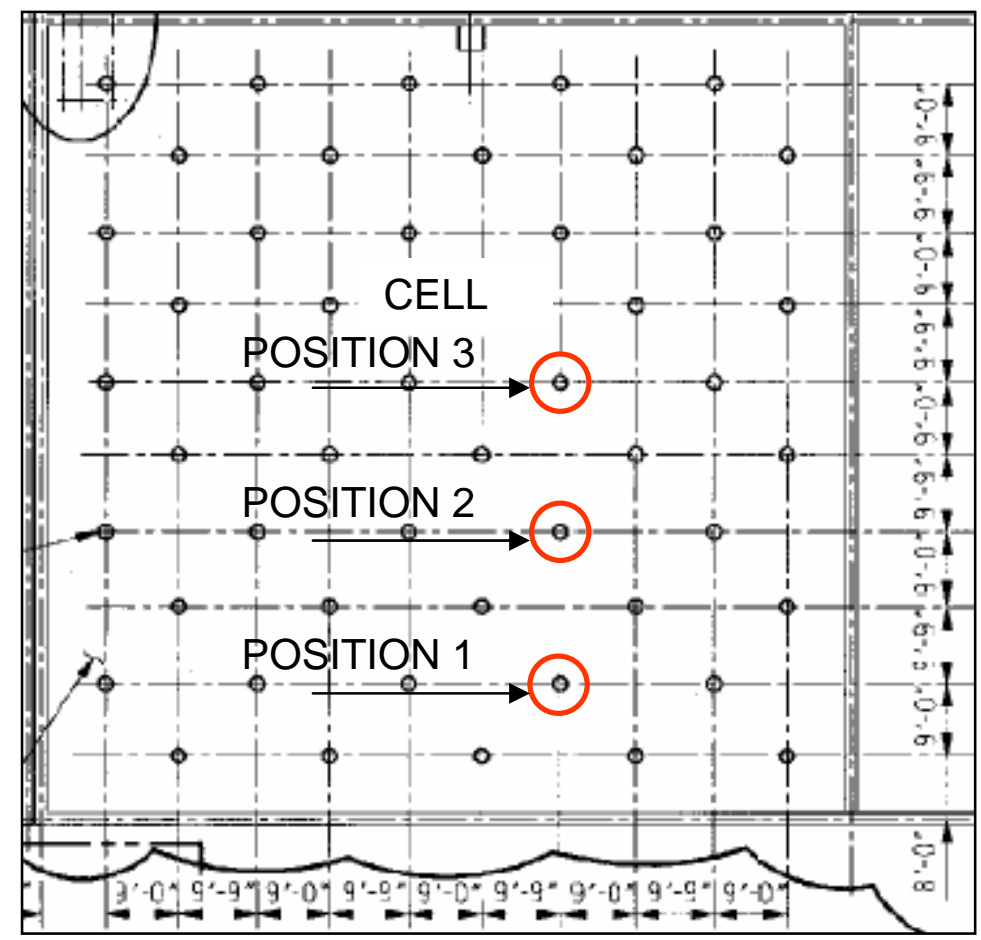

Figure 1. Vault 4, Cell E, sample core locations.

Waste Solidification Engineering requested an analysis of a representative core sample. ${ }^{5}$ The request included visual uniformity, mineralogy, microstructure, density/porosity, $\mathrm{K}_{\mathrm{d}}$, and chemical composition. A Task Technical and Quality Assurance Plan (TTQAP) was issued to detail the recommended analysis. ${ }^{6}$ Analysis for chemical composition, permeability, and $\mathrm{K}_{\mathrm{d}}$ were deferred to out year support. 


\subsection{Experimental}

Prior to preparing samples and performing the analysis on the field collected core sample, the methodologies of the first time evolutions were demonstrated on laboratory prepared simulant samples. Laboratory prepared simulants were used to demonstrate sectioning of cylindrical samples for permeability testing (to be performed with out year funding) and mounting and polishing subsamples for microscopic analysis.

\section{$2.1 \underline{\text { Simulant }}$}

\subsubsection{Salt Solution Preparation}

Table 2-1 is the composition of Tank 50 as reported in the Waste Characterization System (WCS) at the time the Saltstone Production Facility (SPF) was operating. This composition and operational window correspond to the field samples collected during coring activities ${ }^{1}$. The table omits radionuclides or organics. The composition of the simulant salt solution used for the laboratory prepared samples was based on the composition in Table 2-1 using the components with concentrations greater than $0.001 \mathrm{M}$ with the exception of chloride. The omission of chloride was based on work that indicates no effect of chloride on grout properties of interest. ${ }^{7}$ Sulfate and phosphate were included as Reference ${ }^{7}$ demonstrated that, even at low concentrations, the presence of either sulfate or phosphate anions affected grout properties.

Table 2-1. Composition of Tank 50 as of 11/30/07 as Reported by WCS.

\begin{tabular}{|c|c|c|}
\hline \multirow{2}{*}{ Component } & \multicolumn{2}{|c|}{ Concentration } \\
\hline & $\mathrm{mg} / \mathrm{L}$ & $\mathbf{M}$ \\
\hline $\mathrm{NH}_{4}^{+}$ & 83.4 & 0.00 \\
\hline $\mathrm{CO}_{3}{ }^{2-}$ & 3194.3 & 0.05 \\
\hline $\mathrm{Cl}^{-}$ & 229.7 & 0.01 \\
\hline $\mathrm{F}^{-}$ & 16.2 & 0.00 \\
\hline $\mathrm{OH}^{-}$ & 21973.5 & 1.29 \\
\hline $\mathrm{NO}_{3}^{-}$ & 200835.9 & 3.24 \\
\hline $\mathrm{NO}_{2}^{-}$ & 1466.6 & 0.03 \\
\hline $\mathrm{C}_{2} \mathrm{O}_{4}^{-}$ & 665.5 & 0.01 \\
\hline $\mathrm{PO}_{4}^{-}$ & 225.1 & 0.002 \\
\hline $\mathrm{SO}_{4}^{-}$ & 422.9 & 0.004 \\
\hline As & 0.1 & 0.00 \\
\hline $\mathrm{Ba}$ & 1.8 & 0.00 \\
\hline $\mathrm{Cd}$ & 0.3 & 0.00 \\
\hline $\mathrm{Cr}$ & 12.5 & 0.00 \\
\hline $\mathrm{Pb}$ & 1.3 & 0.00 \\
\hline $\mathrm{Hg}$ & 57.5 & 0.00 \\
\hline Se & 0.1 & 0.00 \\
\hline $\mathrm{Ag}$ & 0.6 & 0.00 \\
\hline $\mathrm{Al}$ & 6689.7 & 0.25 \\
\hline $\mathrm{Na}$ & -- & 4.5 \\
\hline
\end{tabular}

Table 2-2 is the composition of the salt solution used for the simulant to produce all of the Saltstone samples used in this study. To prepare the simulant salt solution from Table 2-1, reagents were selected to meet the desired concentrations of the individual analytes and maintain charge balance in the solution. To meet these criteria, the source of aluminum was divided between sodium aluminate and aluminum nitrate to obtain the appropriate aluminum concentration and nitrate concentration. The sodium value was the variable used to achieve charge balance. The initial simulant was prepared in a volumetric flask. The components were 
added to water and mixed until no visible solids remained. Water was added to attain the desired volume. Subsequent simulant were prepared in 15-L carboys using water additions scaled from the water needs determined in the initial simulant. The measured density and the weight percent solids of the simulant correspond well with density and the weight percent solids of the salt solution- $1.222 \mathrm{~g} / \mathrm{mL}$ and $26.20 \%$ respectively - sampled from Tank 50 in November $2006 .{ }^{8}$ Density and weight percent solids measurements were performed on each simulant batch to verify that the batches were properly prepared.

Table 2-2. Composition of Simulant Salt Solution

\begin{tabular}{|c|c|c|}
\hline \multirow{2}{*}{ Component } & \multicolumn{2}{|c|}{ Concentration } \\
\hline & $g / L$ & $\mathbf{M}$ \\
\hline $\mathrm{NaOH}(\mathrm{w} / \mathrm{w} 50.5 \%)$ & 103.3 & 1.29 \\
\hline $\mathrm{NaNO}_{3}$ & 212.3 & 2.50 \\
\hline $\mathrm{NaNO}_{2}$ & 2.19 & 0.03 \\
\hline $\mathrm{Na}_{2} \mathrm{CO}_{3}$ & 5.63 & 0.05 \\
\hline $\mathrm{Na}_{2} \mathrm{C}_{2} \mathrm{O}_{4}$ & 1.01 & 0.01 \\
\hline $\mathrm{Na}_{2} \mathrm{SO}_{4}$ & 0.62 & 0.004 \\
\hline $\mathrm{Na}_{2} \mathrm{Al}_{2} \mathrm{O}_{4} \cdot 2 \mathrm{H}_{2} \mathrm{O}$ & 12.71 & $0.06(0.127 \mathrm{Al})$ \\
\hline $\mathrm{Al}\left(\mathrm{NO}_{3}\right)_{3} \cdot 9 \mathrm{H}_{2} \mathrm{O}$ & 45.15 & 0.12 \\
\hline $\mathrm{Na}_{3} \mathrm{PO}_{4} \cdot 12 \mathrm{H}_{2} \mathrm{O}$ & 0.90 & 0.002 \\
\hline Total Na & - & 4.47 \\
\hline \multicolumn{3}{|l|}{ Properties } \\
\hline Density & 1.222 & $\mathrm{~g} / \mathrm{mL}$ \\
\hline Wt \% total solids & 28.52 & $\%$ \\
\hline
\end{tabular}

\subsubsection{Grout Preparation}

Premix components cement, granulated blast furnace slag and Class F fly ash were obtained from the Z-Area Saltstone facility. In the first quarter of CY09, the SPF revised the specifications for fly ash. ${ }^{9}$ Archived Class $\mathrm{F}$ fly ash obtained prior to the new specification was used for all samples prepared in this study. Premix components were blended in the ratio of 10/45/45 cement/slag/fly ash and mixed with the appropriate amount of salt solution to make the Saltstone grout run during 4Q07 SPF operations. ${ }^{10}$ Table 2-3 is the mix used for all of the Saltstone simulants prepared in this study. Although the SPF used both a set retarder and antifoam in operations, these admixtures were omitted from the simulant mix as emulation of the fresh properties of the grout was outside the scope of this work.

Table 2-3. Saltstone Mix Proportions for Simulant Grout.

\begin{tabular}{|c|c|c||}
\hline \multirow{2}{*}{ Component } & Premix & Saltstone \\
\cline { 2 - 3 } & $\mathbf{\%}$ & $\mathbf{\%}$ \\
\hline Salt Solution & 0 & 46.8 \\
\hline $\begin{array}{c}\text { Water (71.48\% of salt } \\
\text { solution) }\end{array}$ & 0 & (33.5 as salt solution) \\
\hline Water to Premix Ratio & -- & 0.63 \\
\hline Cement & 10 & 5.3 \\
\hline Slag & 45 & 23.9 \\
\hline Fly Ash & 45 & 23.9 \\
\hline
\end{tabular}

\subsubsection{Sample Preparation}

Simulant grout slurries were cast into either 2-inch PVC cylinders or 5-gallon pails, Figure 2. The cast cylinders were used to develop the sample cutting technique and to provide a laboratory-cast sample for permeability to compare to the permeability of a cored sample of the same sample 
composition. The 5-gallon pail was cored by SRNL/RRSE using the same method developed for collecting the core samples from Vault 4, Cell E, Figure $3 .^{3}$ Cores were used to demonstrate sample sectioning technique and provide permeability link between lab prepared and field collected (cored) samples. Salt solution from Table 2-2 was added to the cylinders and pails to maintain saturated conditions during curing. Collected core samples were stored in salt solution.
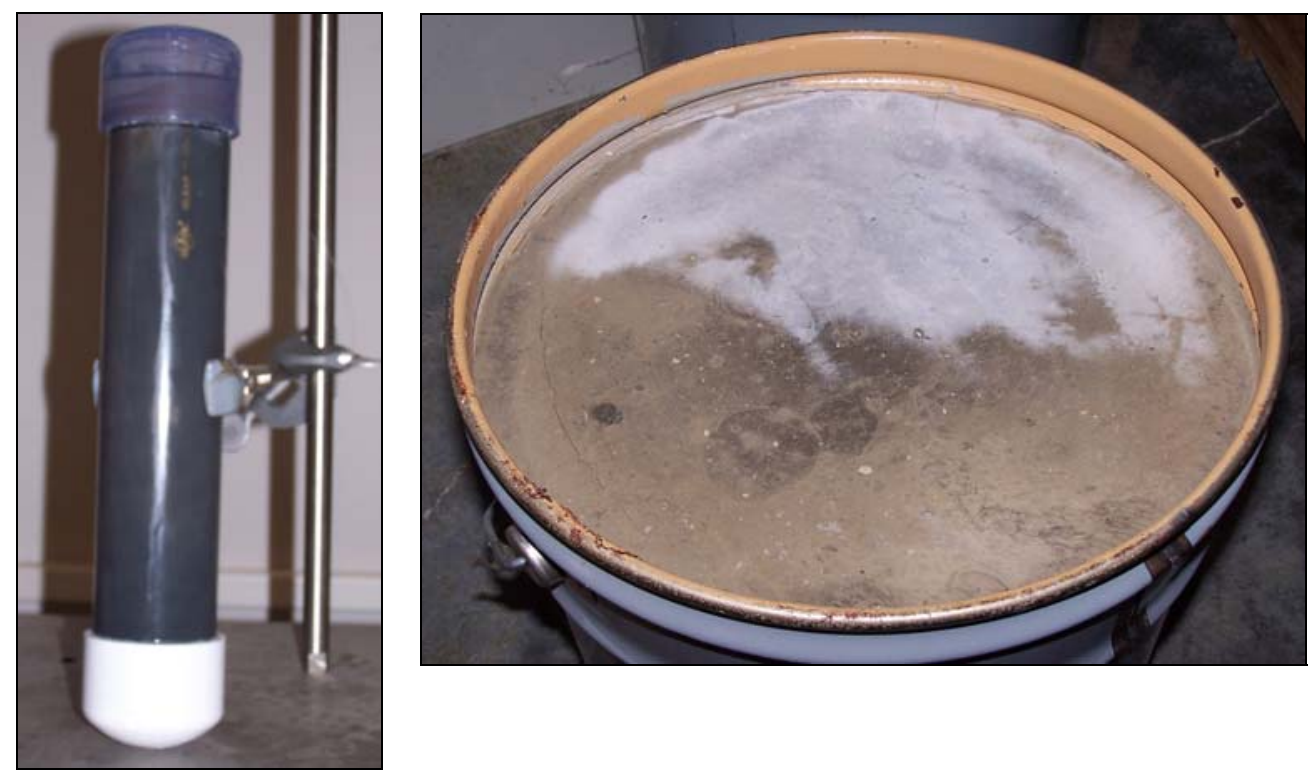

Figure 2. Simulated grout samples cast for method development.
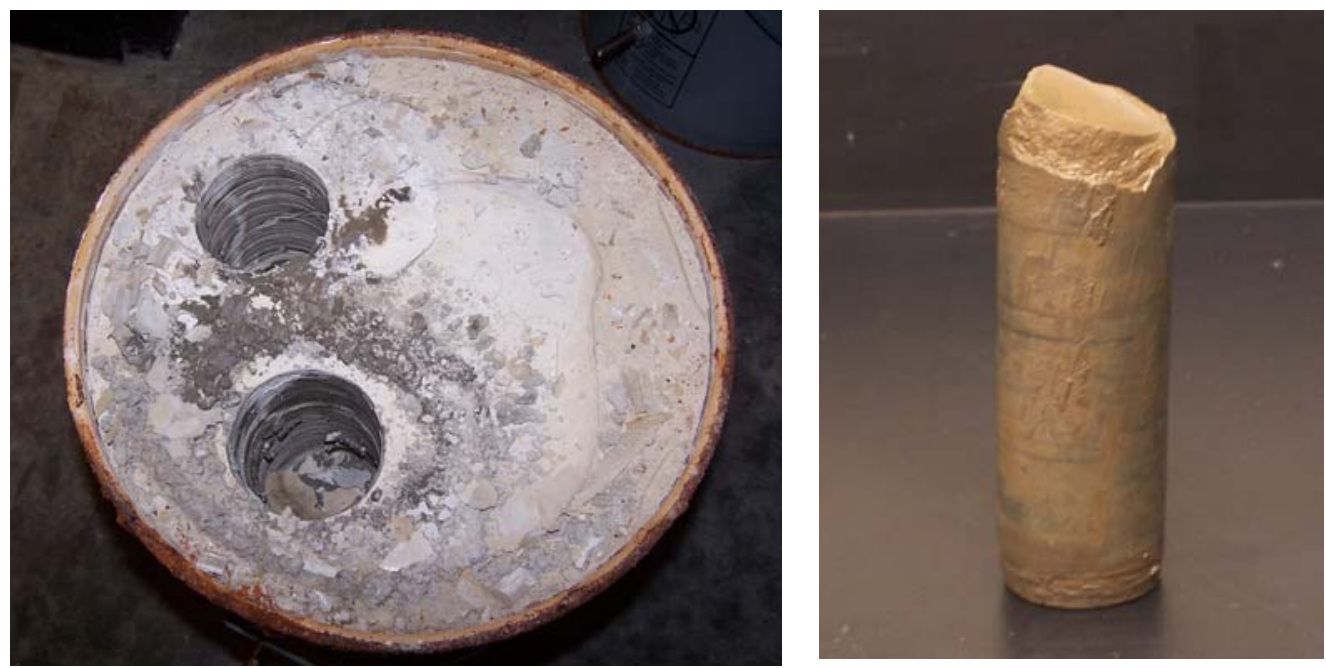

Figure 3. Cored 5-gallon pail and core.

\subsubsection{Sample Sectioning}

Core samples require sectioning for permeability measurements. A miter box saw, Figure 4, was evaluated by cutting archived grout samples. Modifications were made to accommodate smaller work pieces and for operation in a radiohood. The saltstone simulant samples in cast cylinders were not removed from the PVC prior to sectioning. The primary purpose of sectioning samples is to provide right cylinders for permeability testing. 


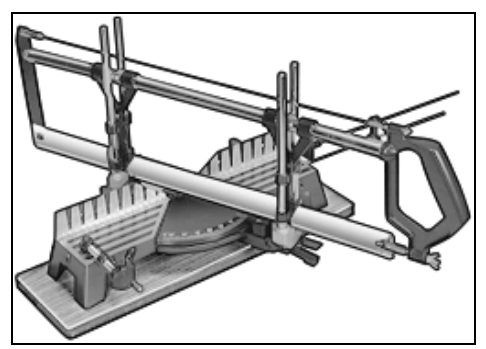

Figure 4. Schematic of miter box saw used for sectioning core samples.

\subsection{Vault 4, Cell E Core}

\subsubsection{Visual Inspection}

In April 2009, the core samples were removed from the evacuated sample container, Figure 5, inspected, and transferred to PVC containers and backfilled with nitrogen for continued storage. ${ }^{11}$

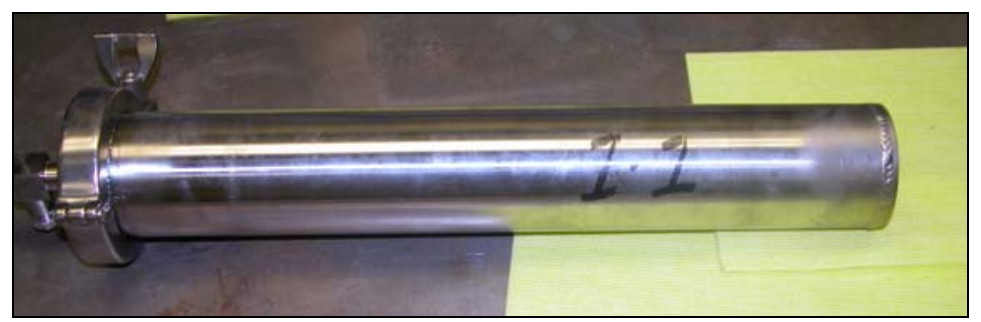

Figure 5. Stainless Steel Vault 4 Sample Container used to transport/store core samples.

Samples from location 3 (furthest from the wall) were the most intact cylinder shaped cored samples. The shade of the core samples darkened as the depth of coring increased. Samples that were not stored in stainless steel containers and evacuated were noticeably lighter in shade. Based on the visual inspection performed, sample 3-3 shown in Figure 6, was selected for all subsequent analysis.

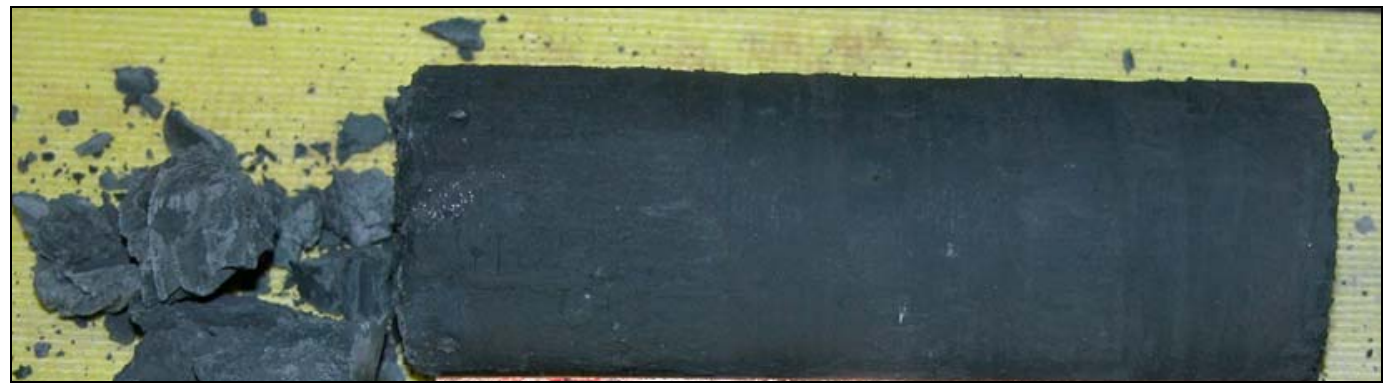

Figure 6. Sample 3-3. 5.5” long cylinder and associated fragments.

\subsubsection{Sample Sectioning}

The miter box saw in Figure 4 was used to prepare samples for hydraulic conductivity measurements. A one-half inch section was trimmed off the end of sample 3-3 to provide a newly exposed surface. 


\subsubsection{Density and Porosity}

During sectioning activities, three fragments of the core were stored for density and porosity measurements using ASTM C 642 "Standard Test Method for Density, Absorption, and Voids in Hardened Concrete." In the procedure, the test specimen is specified to be no less than $350 \mathrm{~cm}^{3}$ ( $\sim 850$ g normal weight concrete). This criterion was not achievable as the entire core was $\sim 122$ $\mathrm{cm}^{3}$. The fragments used were similar in size and the fragments each weighed approximately 10$14 \mathrm{~g}$. Following the procedure, samples were dried at $110^{\circ} \mathrm{C}$ and weighed intermittently until the difference between any two successive values is less than $0.5 \%$ of the lowest value obtained, $\mathrm{W}_{\mathrm{D}}$. The dried, cooled samples were then immersed in liquid. The samples were weighed intermittently until two successive values of mass of the surface-dried sample at intervals of $24 \mathrm{~h}$ show an increase in mass of less than $0.5 \%$ of the larger value, $\mathrm{W}_{\mathrm{I}}$. The ASTM procedure instructs immersion of the samples in water to determine the saturated mass. Given that the core samples were produced using salt solution, the immersion fluid used for these measurements was the salt simulant in Table 2-2. To obtain the saturated mass after boiling, the samples were boiled in the salt solution for five hours. Additional salt solution was added as needed during boiling to keep the samples submerged. The sample fragments were allowed to cool and the surface-dried mass was measured, $\mathrm{W}_{\mathrm{IB}}$. The samples were submerged and the suspended mass was measured, $\mathrm{W}_{\text {IBS}}$. The bulk density of the immersed sample was calculated by the equation

$$
B D_{I}=\frac{W_{I}}{W_{I B}-W_{I B S}} \times \rho
$$

where; $\mathrm{BD}_{\mathrm{I}}$ is the bulk density of the immersed sample as defined by ASTM C $642, \mathrm{~W}_{\mathrm{I}}$ is the mass of the sample immersed in salt solution and surface dried, $\mathrm{W}_{\mathrm{IB}}$ is the mass of the sample immersed and boiled in salt solution and surface dried, $\mathrm{W}_{\mathrm{IBS}}$ is the mass of the sample boiled in salt solution, cooled, and then suspended, and $\rho$ is the density of the salt solution after boiling.

The porosity of the samples was calculated by the equation

$$
\text { Porosity } \%=\frac{\left(W_{I B}-W_{D}\right)}{\left(W_{I B}-W_{I B S}\right)} \times 100
$$

where; $\mathrm{W}_{\mathrm{D}}$ is the mass of the sample immersed in salt solution and surface dried, $\mathrm{W}_{\mathrm{IB}}$ is the mass of the sample immersed and boiled in salt solution and surface dried, and $\mathrm{W}_{\mathrm{IBS}}$ is the mass of the sample boiled in salt solution, cooled, and then suspended.

It is assumed that by drying the samples prior to measurement that the void space contains only air (no water).

\subsubsection{Microstructure}

By design, the coring in cell position 3, Figure 1, traversed three SPF operating days that resulted in three pouring lifts in the SDF. ${ }^{1} \mathrm{XRD}$ analysis was performed on fragments from cores from each of the three cores collected from cell position 3. The core sampling X-ray Diffraction Analysis (XRD) was performed on the as-collected core samples 3-1, 3-2, and 3-3. Approximately $0.25 \mathrm{~g}$ of each of the cores was submitted for analysis.

Fragments of the trimmed core sample 3-3 described in Section 2.2.2 were analyzed using various microscopic techniques. Optical microscopy and scanning electron microscopy (SEM) were used to evaluate fresh fractured surfaces and polished surfaces. In addition to standard SEM imaging using secondary electrons (SEI), images were obtained using the detector for backscattered 
electrons (BSE). Imaging with the BSE detector provides information about the distribution of different elements in the sample. On select images, Energy Dispersive X-ray Spectroscopy (EDS) was used to determine the relative elemental composition of the sample.

\subsection{Results and Discussion}

\subsection{Sample Sectioning}

To demonstrate the soundness of the approach, the sectioning methodology was used on the lab prepared samples, Figure 2, and the lab cored samples, Figure 3. The first cut of the lab cored sample removed the end of the core. The sample was advanced two inches and the second cut completed the sample. The samples cut under the weight of the saw. The as-cut surface was sufficiently smooth to eliminate the need for additional surface preparation for permeability measurements. For the lab prepared sample, sections approximately two inches long were cut from the cylinder, removed from the PVC, and stored in the simulant salt solution in Table 2-2. Cored simulant samples were removed from the salt solution, wiped dry, cut into two 2-inch sections, and then retuned to the salt solution.

The Vault 4, Cell E cored sample 3-3 was removed from the storage container as described in Reference 11. As with the lab cored sample, the first cut removed the end of the core. Two 2-inch samples were cut and stored in the simulated salt solution in Table 2-2. The samples were cut using the weight of the saw. When cutting the Vault 4 core sample, more material was removed with each stroke than when cutting the lab cored sample.

\subsection{Density and Porosity}

Table 3-1 is the mass used for the core fragments after each of the procedure steps performed in Section 2.2.3. Using Equations (1) and (2) in Section 2.2.3, the bulk density after immersion and boiling, $\mathrm{BD}_{\mathrm{I}}$, and the porosity was calculated, Table 3-2

Table 3-1. Mass of Core Fragments used to Calculate Density and Porosity.

\begin{tabular}{|c|c|c|c|c||}
\hline \hline Replicate & $\mathbf{W}_{\mathbf{D}}$ & $\mathbf{W}_{\mathbf{I}}$ & $\mathbf{W}_{\text {IB }}$ & $\mathbf{W}_{\text {IBS }}$ \\
\hline 1 & 7.441 & 11.595 & 12.772 & 3.524 \\
\hline 2 & 8.672 & 13.890 & 15.56 & 4.132 \\
\hline 3 & 9.539 & 15.809 & 17.694 & 4.508 \\
\hline
\end{tabular}

Table 3-2. Bulk Density and Porosity of Core Sample 3-3 Using ASTM C 642.

\begin{tabular}{|c|c|c|}
\hline Replicate & BD $_{\mathbf{I}}$ & Porosity (\%) \\
\hline 1 & 1.92 & 57.64 \\
\hline 2 & 1.89 & 60.27 \\
\hline 3 & 1.86 & 61.85 \\
\hline Average & 1.90 & 59.90 \\
\hline
\end{tabular}

The density and porosity of Saltstone prepared with simulated salt solutions representing projected salt compositions for out year processing in the SPF. ${ }^{12}$ It was demonstrated that the salt solution, water-to-premix ratio and premix blend effect the bulk density and porosity of the final product. In the work performed in Reference 12, the DDA simulant most closely resembles the salt solution in Table 2-1. The values measured for the Vault 4 core sample in Table 3-2 correlate well with the bulk density and porosity values reported for the Saltstone prepared with DDA simulant-1.78-1.81 g.cm ${ }^{3}$ and 59.1-62.4\%, respectively. 


\subsection{Microstructure}

\subsubsection{X-ray Diffraction Analysis}

Figure 7 is the XRD patterns of the three core samples collected from cell position 3.

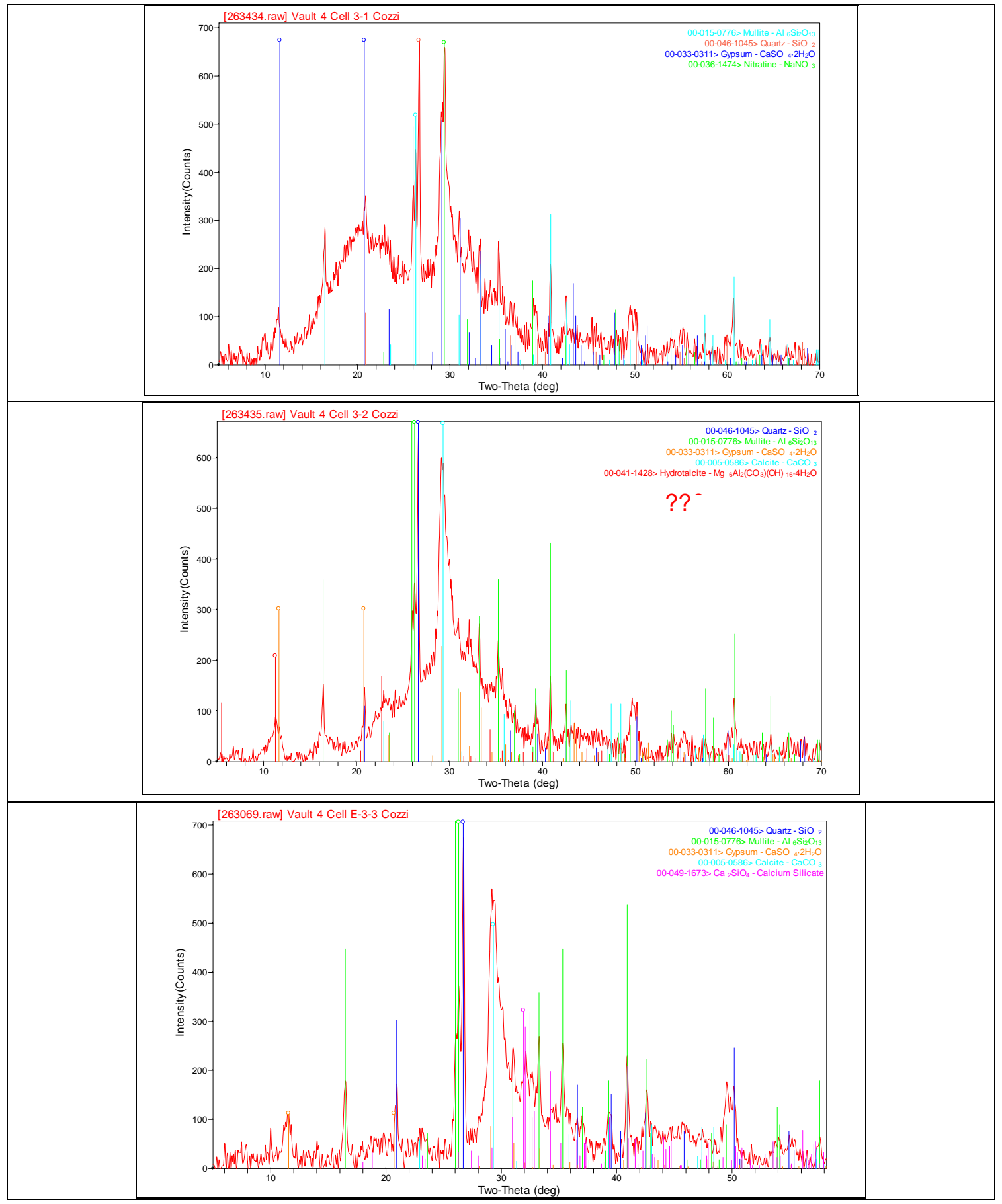

Figure 7. X-ray diffraction analysis of the three core samples collected from cell position 3.

Phases common to each of the samples are mullite, quartz, and gypsum. Mullite and quartz are associated with the crystalline portion of fly ash. Although less common, gypsum can also be 
attributed to the fly ash. The occurrence of gypsum in fly ash is indicative of wet treatment or storage. ${ }^{13}$ In addition to these phases being common to all of the samples, they are also the most predominant crystalline phases. This corresponds well with the abundance of fly ash in the mix and the limited reactivity of the fly ash. ${ }^{14}$ Hydrotalcite, a hydration phase associated with slag, is only identified in the 3-2 XRD pattern. Hydrotalcite may be present in all of the samples, however, the peaks associated with this phase can be obscured by the peaks associated with gypsum. ${ }^{15}$ Sodium nitrate was identified in the XRD pattern for sample 3-1. The sodium nitrate is a component of the salt solution and could be expected in all of the samples. However, since the samples were prepared and analyzed with minimal handling, there may be sufficient pore water to preclude the sodium nitrate from crystallizing to an extent sufficient enough to be positively identified by XRD. The amorphous hump near $30^{\circ} 2 \theta$ in the spectra is indicative of the presence of calcium silicate hydrate (CSH) gel.

\subsubsection{Optical Microscopy}

The end piece of core sample 3-3, Figure 6, was shattered to provide fragments for microscopic analysis, Figure 8. The rind of light material is due to oxidation that occurred in the ten days of storage in a plastic bag between sectioning and fracture. Fragments were collected to maximize exposure surfaces of the interior for microscopy.

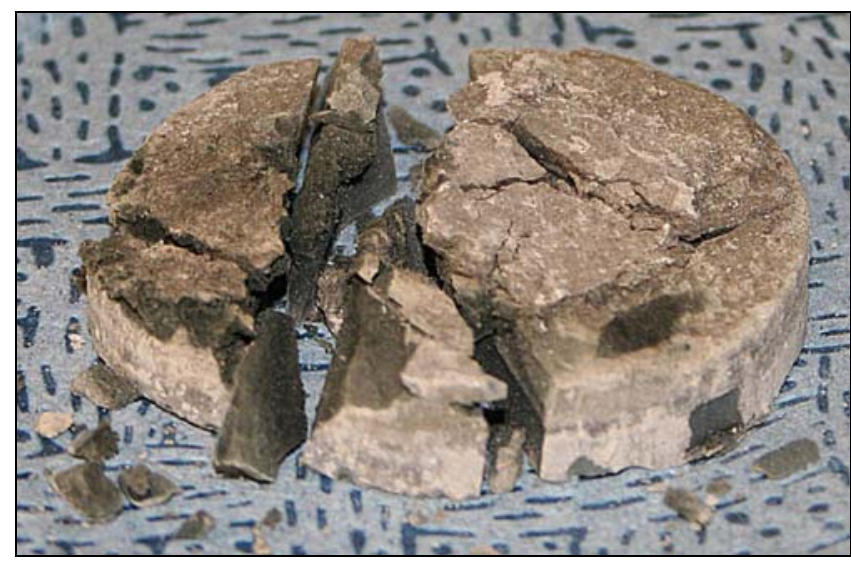

Figure 8. Shattered core section used for microscopy.

A fragment of the sample with the interior exposed was mounted for optical microscopy. Figure 9 is a representative 100x photo of the mounted specimen prior to polishing. The mounted sample showed signs of oxidation in the mounting process. Overall, the sample shows a uniform presence of porosity and inclusions. The larger round openings are where fly ash has been. Fly ash used in the SPF at the time of processing had a mean particle size of $52 \mu \mathrm{m}$ and $95 \%$ of the particles $>163 \mu \mathrm{m} .{ }^{16}$ The red coloration in the Figure 9 can be attributed to iron associated with the fly ash. Reference 16 identifies a substantial quantity of magnetic iron compounds associated with fly ash. Photographs were taken using magnifications from 5-150x with no evidence of cracking at any magnification.

After polishing, the sample was photographed at 100x magnification, Figure 10. In this photo, the fly ash particles denoted by the two upper arrows are still present, whereas the particle identified by the lowest arrow has been pulled out during sample preparation. 


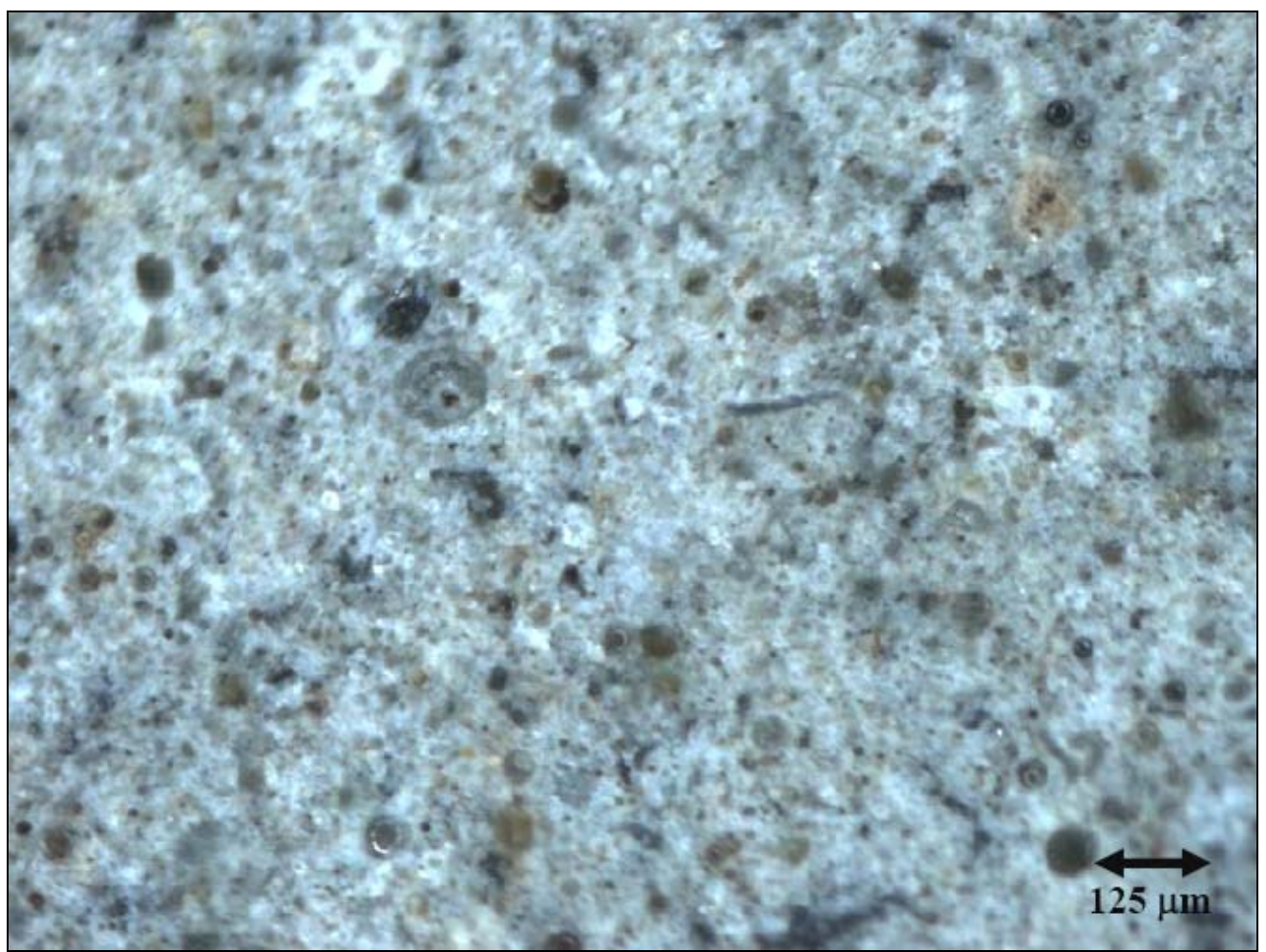

Figure 9. Mounted Vault 4 core specimen fragment interior prior to polishing, 100x.

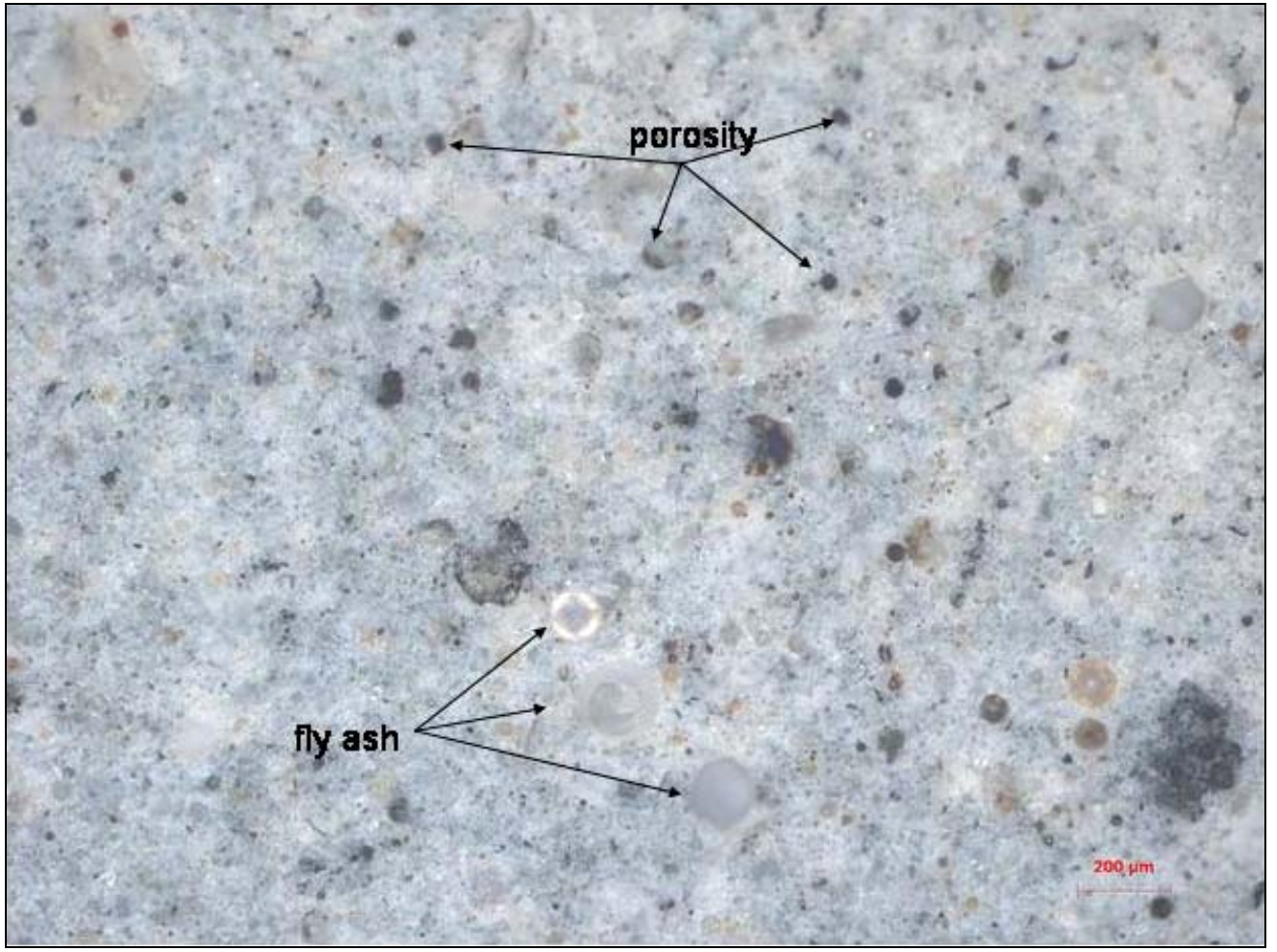

Figure 10. Polished Vault 4 core sample noting fly ash and porosity sites, 100x. 


\subsubsection{Electron Microscopy}

A five millimeter fragment of fresh fractured core sample was mounted for SEM/EDS analysis. Figure 11 shows the fracture surface (SEI) and corresponding backscatter electron image (BSE) for the as mounted fragment. The gaps in the top image are approximately $80 \mu \mathrm{m}$ wide and between $600-800 \mu \mathrm{m}$ long. These gaps are inherent on the sample and do not appear to be an artifact of sample handling. The BSE image has spherical particles dispersed throughout the sample. Also evident is a crack crossing the sample. The crack may be attributed to sample preparation since this analysis requires placing the sample in a vacuum, which can dry the Saltstone sample and introduce cracking.

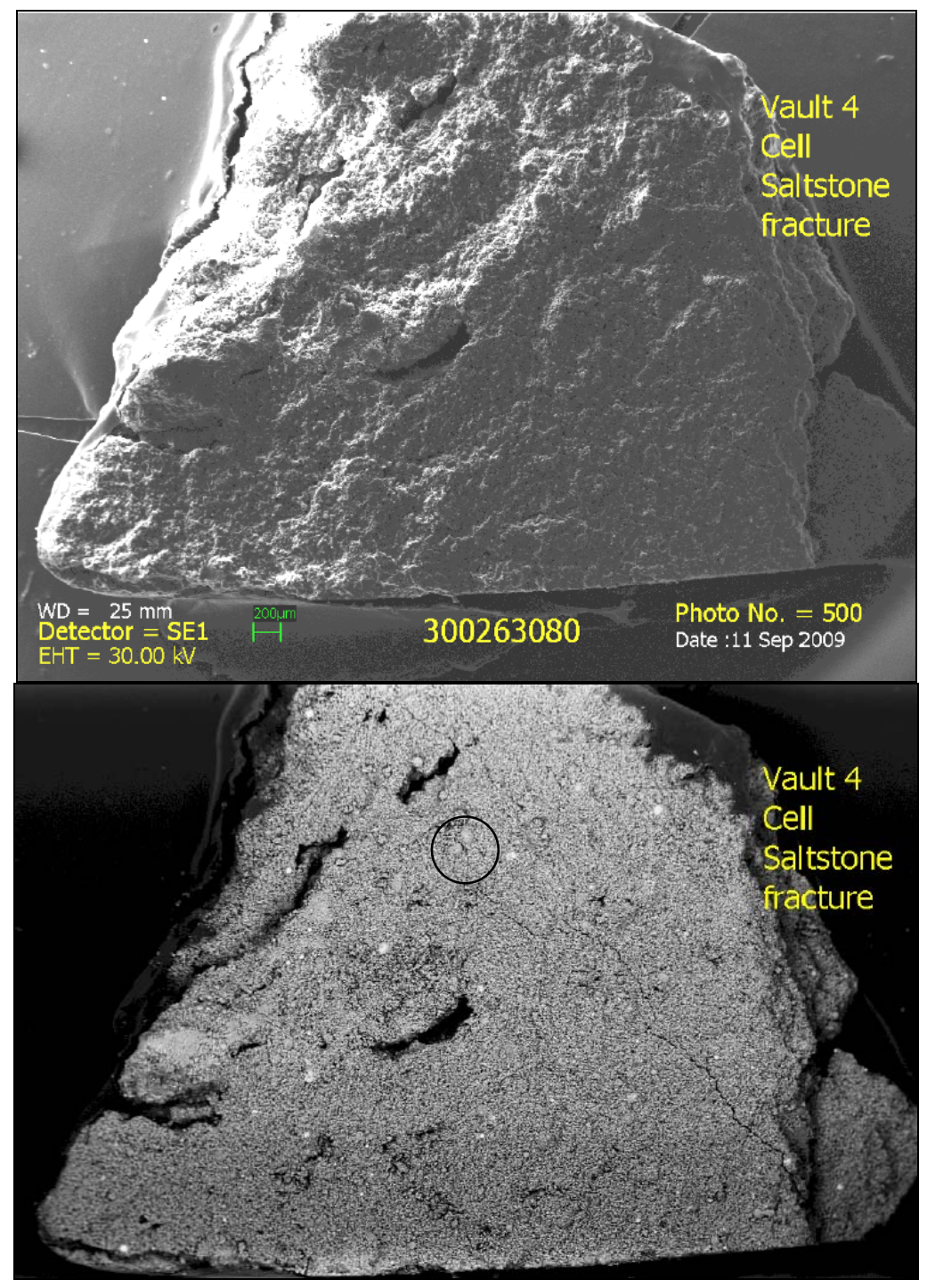

Figure 11. Micrographs showing the as-fractured surface of a fragment of the Vault 4 core sample and the corresponding BSE image, 2.5x.

Figure 12 is the area in the lower micrograph in Figure 11. These micrographs taken at a magnification of 40x show electron micrographs of the morphology and elemental distribution in the Vault 4 core sample. 

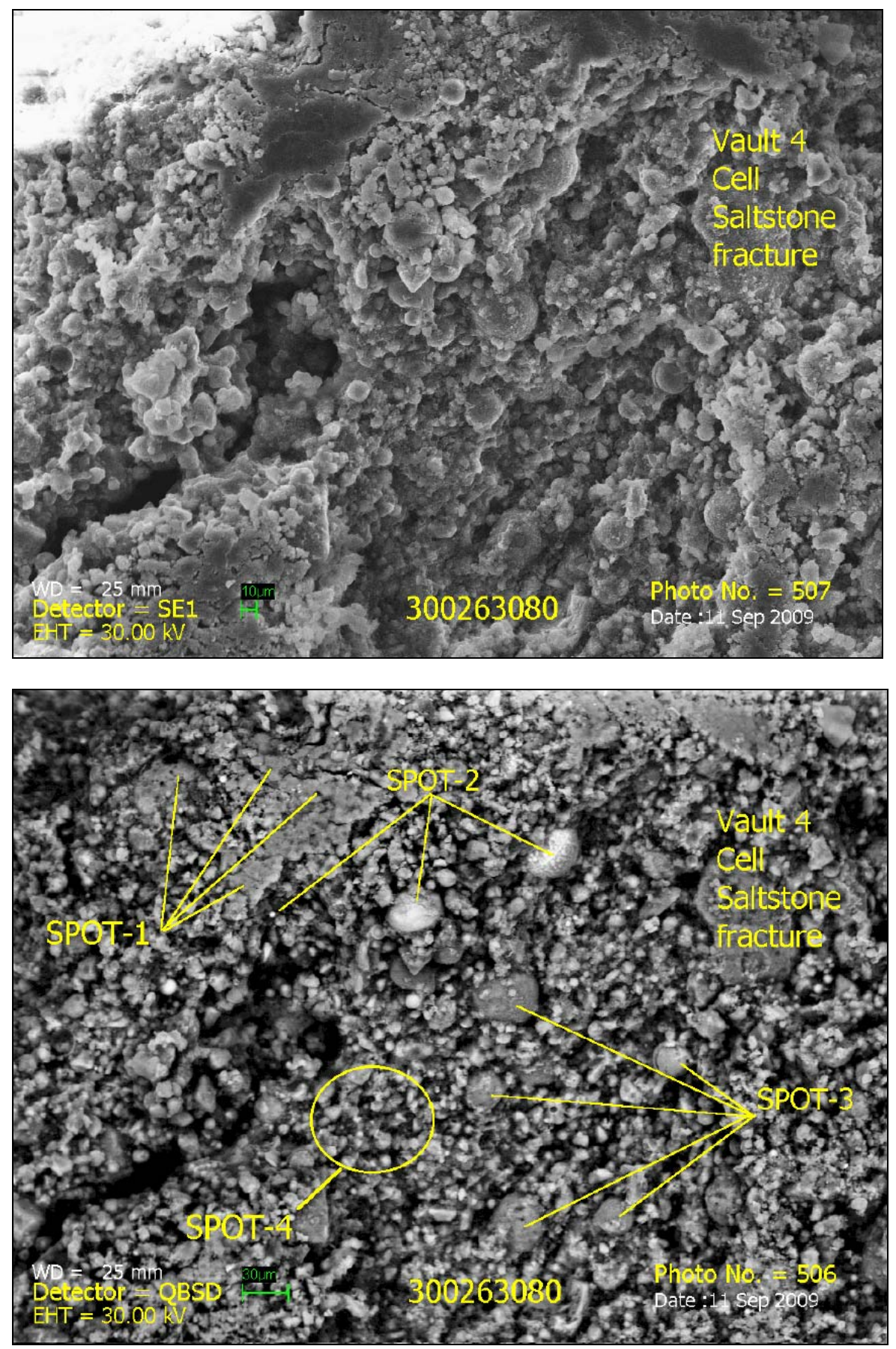

Figure 12. Representative micrographs of the fractured core sample. Top-Secondary electron image showing the morphology of the Vault 4 core sample. BottomCorresponding backscatter electron image annotated with the EDS spectra positions in Figure 13

In the top micrograph (photo No. 507) in Figure 12, the spherical nature of the particles seen in Figure 12 is evident. In the bottom micrograph, the annotated spots were analyzed using EDS, Figure 13. The difference in contract between the spheres in spot-2 and spot- 3 indicate that the spheres are of different compositions. 
At the magnification of 40x, the spots are an aggregate composition of the area being evaluated. The areas in spot-1 are represented by the EDS spectrum in Figure 13. Spot-1 is predominantly calcium and silicon with smaller amounts of aluminum, magnesium and sodium. Considering the composition of the salt solution, the XRD analysis and the micrographs, it can be inferred that these points in spot- 1 represent calcium silicate hydrate (CSH) gel, tricalcium aluminate (C3A), hydrotalcite, and salt from the salt solution. The spheres in spot-2 are predominantly iron with silicon, aluminum, and calcium. Recalling the abundance of magnetic iron compounds in fly ash discussed in Reference 16 and the higher atomic number of the components of these spheres as identified in the BSE micrograph in Figure 12, these spheres are the iron oxide phases from fly ash. The EDS spectrum for the spheres in spot-3 coupled with the XRD analysis would indicate that the spheres are the unreacted quartz $\left(\mathrm{SiO}_{2}\right)$ and mullite $\left(3 \mathrm{Al}_{2} \mathrm{O}_{3} \cdot 2 \mathrm{SiO}_{2}\right)$ in the fly ash. Spot-4 is an overall EDS spectrum of an area and reflects the overall composition of the Saltstone (premix components and salt solution).
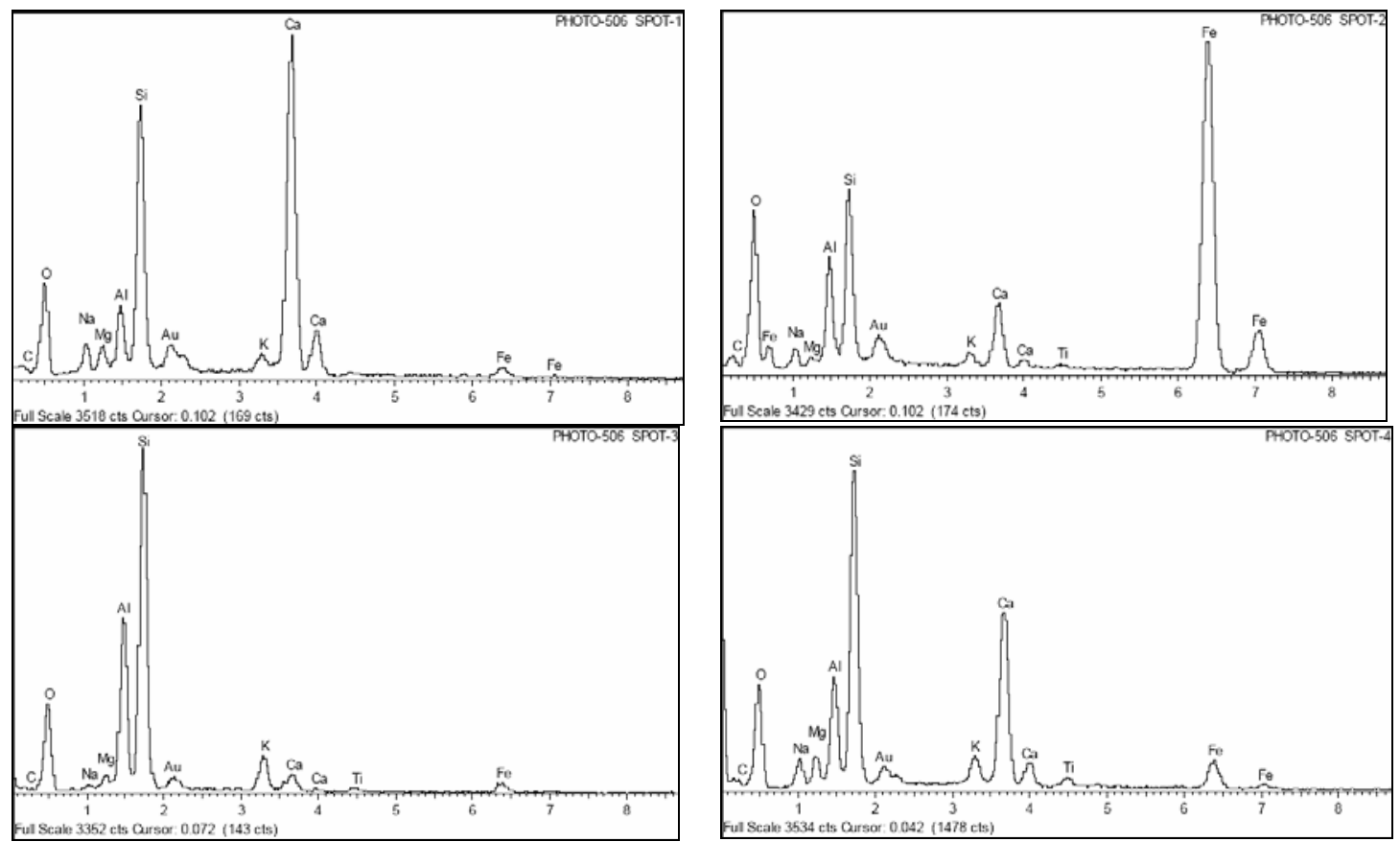

Figure 13. EDS spectra for the four locations annotated in Figure 12.

SEM/EDS analysis was performed on a polished sample of the Vault 4 core sample. Figure 14 is representative micrographs of the polished sample. The cavities in the micrographs are remnants of fly ash particles (either the glassy phase or the ferrite spinel phase) that pulled out during sample preparation. In the smaller cavities on the left of the micrograph, smaller spheres line the inside of the cavity. These spheres could be the unreacted mullite and quartz phases of fly ash. The more intact spheres that are more pronounced in the BSE micrograph are fly ash particles that remained embedded in the sample. The large cavity on the right is a glassy cenosphere, also attributed to the fly ash. ${ }^{17}$ 
SRNL-STI-2009-00804

Revision 0

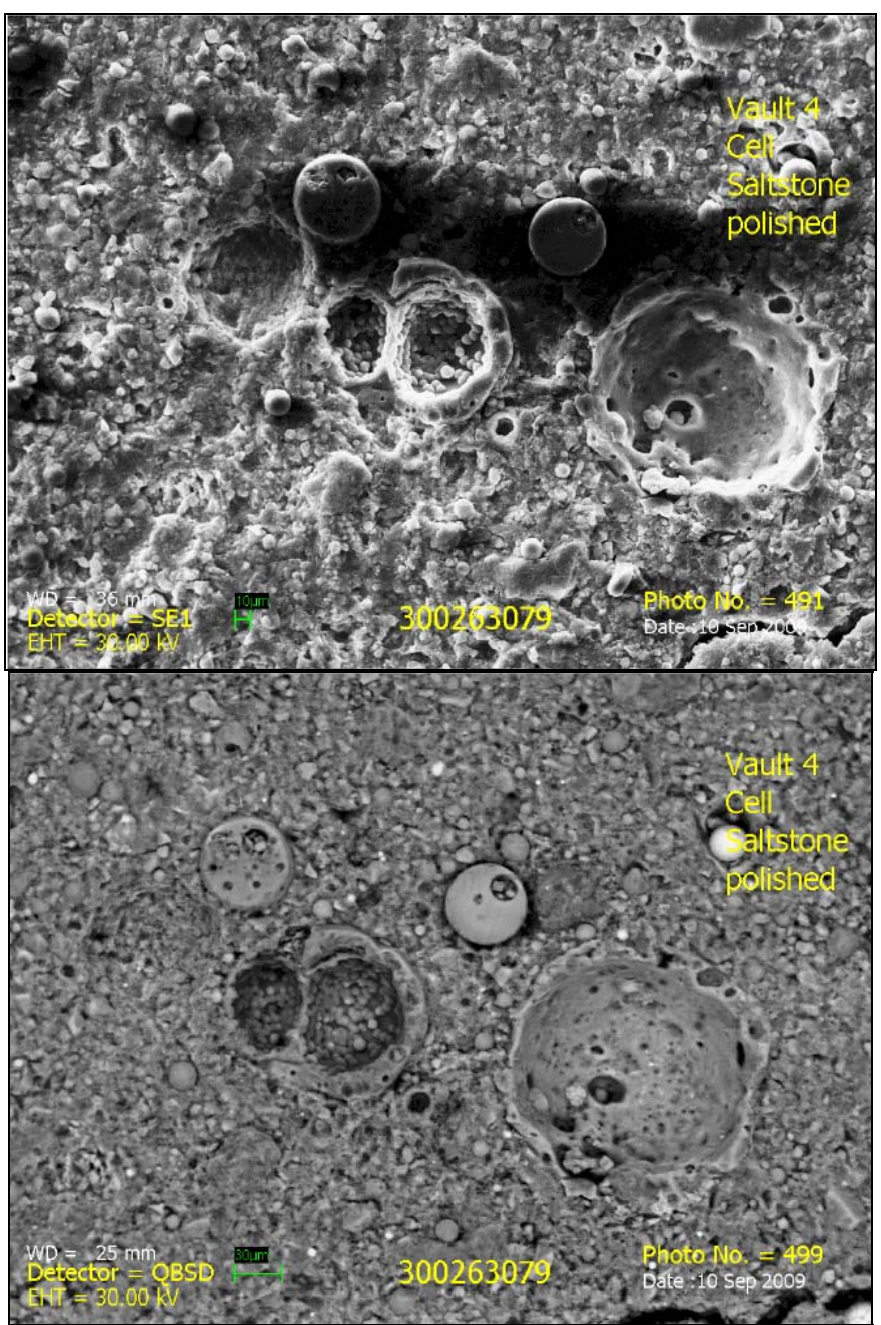

Figure 14. SEM micrographs of the polished Vault 4 core sample, 200x. Top-SEI and Bottom-BSE.

\subsection{Conclusions}

Core samples were collected from the Saltstone Disposal Facility Vault 4, Cell E. Visual inspection of the cores showed that the dry cored samples were darker in tone than the wet cored samples. Core 3-3, a dry cored sample, was used for all of the subsequent analyses. A sectioning methodology was demonstrated with simulants using a hand miter saw to prepare samples for future permeability measurements. This technique was applied to the Vault 4 core sample. Sectioning of the Vault 4 core sample was marginally easier than sectioning of the lab cored simulant.

The density and porosity of the Vault 4 core sample, $1.90 \mathrm{~g} / \mathrm{cm}^{3}$ and $59.90 \%$ respectively, were comparable to values achieved for laboratory prepared samples using water-to-cementitious materials ratios, premix blends, and simulated salt solutions with compositions and properties similar to the salt solution in Table 2-1.

X-ray diffraction analysis of the Vault 4 core samples from position 3 identify phases consistent with the presence of fly ash, sodium nitrate salt solution, and calcium silicate hydrates - a product 
of the hydration of cement and slag. Microscopic analysis revealed morphology features characteristic of cementitious materials with fly ash and CSH gel.

When taken together, the results of the density, porosity, x-ray diffraction analysis and microscopic analysis support the conclusion that the Vault 4, Cell E core sample is representative of the expected waste form.

\subsection{Recommendations}

To fulfill the scope of the TTQAP ${ }^{6}, K_{d}$ and chemical composition of the saltstone need to be measured. Two core samples of sample 3-3 from Vault 4, Cell E are currently stored for permeability testing. When the methodology has been established, these samples should be analyzed. Based on visual observations during core transfers ${ }^{11}$, additional samples have been identified as viable for permeability measurements. The cores from 3-1, 3-2, 2-1, 2-2, and 2-3 are sufficiently intact to provide at least a single sample for permeability measurement.

It is also recommended to use the ultrasonic pulse velocity measurement to estimate the elastic modulus of the cores prior to permeability measurements. Testing as part of the saltstone Variability Study has shown that the modulus of a cylinder correlates to the permeability of that cylinder. ${ }^{18}$

\subsection{References}

1. Smith, F.M., "Saltstone Sampling Summary for September 2008," LWO-RIP-2008-00006 Revision 0.

2. Zeigler, K.E., Bibler, N.E., "Results for the Fourth Quarter 2007 Tank 50H WAC Slurry Sample: Chemical Contaminant Results."

3. Cheng, W.Y., Marzolf, A.D., and Milling, R.B., "Recommendations for Improving the Drilled-Core Saltstone Grout Sampling Process," SRNS-STI-2009-00481 Revision 0, August 2009.

4. Hansen, E.K., Crawford, C.L., "Pictures of Vault 4 Core Samples - Transfer of Samples at SRNL - April 6, 2009."

5. Staub, A.V., "Emplace Grout Sample Analysis," HLW-SSF-TTR-2008-0010 Revision 0.

6. Hansen, E.K., and Cozzi, A.D., "Vault 4, Cell E, Grout Sample Analyses," SRNL-TR-200900005 Revision 0.

7. Harbour, J.R., Edwards, T.B., Hansen, E.K., and Williams, V.J., "Variability Study for Saltstone," WSRC-TR-2005-00447, Revision 0, October 2005.

8. Cozzi, A.D., and Hansen, E.K., "Saltstone Formulation Testing for DDA Batch 3," SRNLPSE-2008-00019 Revision 0, January 2008.

9. "Specification for Procurement of Thermally Beneficiated Class F Fly Ash for SPF (U)," XSPP-Z-0002 Revision 2, April 2009.

10. Staub, A.V., "Saltstone Processing History for Third and Fourth Quarter 2007 Operation," LWO-WSE-2007-00216 revision 0, December 2007. 
11. Hansen, E.K., and Crawford, C.C., "Pictures of Vault 4 Core Samples - Transfer of Samples at SRNL - April 6, 2009," SRNL-L3100-2009-00087 Revision 0, April 2009.

12. Harbour, J.R., Williams, V.J., Edwards, T.B., Eibling, R.E., Schumacher, R.F., "Saltstone Variability Study - Measurement of Porosity," WSRC-STI-2007-00352 Revision 0.

13. Walenta, G. and Füllmann, T., "Advances in Quantitative XRD Analysis for Clinker, Cements, and Cementitious Additions," Advances in X-ray Analysis, 47 287-96 (2004).

14. Harbour, J.R., Williams, V.J., Edwards, T.B., "Heat of Hydration of Saltstone MixesMeasurement by Isothermal Calorimetry," WSRC-STI-2007-00263.

15. Gruskovnjak, A., Lothenbach, B., Winnefeld, F., Figi, R., Ko, S.-C., Adler, M., and Mäder, U., "Hydration Mechanisms of Super Sulphated Slag Cement," Cement and Concrete Research, 38 993-2 (2008).

16. Hansen, E.K., and Harbour, J.R., "Comparison of Boral with Cross Station Fly Ash," SRNLPSE-2006-00095 Revision 0, 2006.

17. Kutchko, G.G. and Kim, A.G., "Fly Ash Characterization by SEM-EDS," Fuel, 85 2537-44 (2006).

18. Harbour, J.R., Williams, V.J., "Saltstone Performance Indicator - Dynamic Young's Modulus," SRNL-STI-2008-00488 Revision 0. 
Distribution:

J.L. Adams, 704-14Z

A.B. Barnes, 999-W

C.H. Beheler, 704-14Z

P.L. Bovan, 704-27S

A.D. Cozzi, 999-W

D.A. Crowley, 773-43A

A.D. England, $\quad 704-14 \mathrm{Z}$

S.D. Fink, 773-A

B.J. Giddings, 786-5A

J.C. Griffin, 773-A

J.R. Harbour, 999-W

S.D. Heath, 704-Z

C.C. Herman, 999-W

C.A. Langton, 773-43A

K.R. Liner, 704-S

S.L. Marra, 773-A

P.W. Norris, 704-Z

J.E. Occhipinti, 704-S

E. Patten, 704-Z

F.M. Pennebaker, 773-42A

J.W. Ray, 704-S

M.M. Reigel, 999-W

A.L. Richardson, 210-S

A.R. Shafer, 704-27S

D.C. Sherburne, 704-S

F.M. Smith, 705-1C

A.V. Staub, 704-Z 